DOI: 10.17951/en.2019.4.111-131

\begin{tabular}{lcr}
\hline & ANNALES \\
& UNIVERSITATIS MARIAE CURIE-SKŁODOWSKA & \\
LUBLIN - POLONIA & \\
VOL. IV & SECTIO N & 2019 \\
\hline
\end{tabular}

Justyna Nowotniak

Uniwersytet Szczeciński

ORCID: http://orcid.org/0000-0002-7439-0414

justyna.nowotniak@usz.edu.pl

\title{
Ukryte programy ewaluacji edukacyjnej
}

\section{Hidden Curricula of Evaluation in Education}

Streszczenie: W artykule podniesiono kwestię kategorii ukrytego programu, znajdującego zastosowanie w studiach i badaniach pedagogicznych. Ukryty program ewaluacji edukacyjnej jest przedmiotem analiz. Autorka odniosła się w nich do zagadnienia ewaluacji wewnętrznej wprowadzonej w 2009 roku wraz ze zmianą nadzoru pedagogicznego w Polsce.

Słowa kluczowe: program ukryty; ewaluacja edukacyjna; ewaluacja wewnętrzna; autoewaluacja

\section{WPROWADZENIE}

Diagnoza sposobu funkcjonowania i zarządzania polską szkołą pozwala odczytać wykładnię praktyki ewaluacyjnej mającej w niej miejsce, która zasadniczo wymyka się założeniom teoretycznym ewaluacji i stanowi wiedzę typu know-how. Dominacja owej (nie)wiedzy profesjonalnej stała się przesłanką podjęcia refleksji nad hidden curriculum w odniesieniu do zagadnienia ewaluacji edukacyjnej.

W wielu przypadkach krytyka wymierzona w podmioty edukacji, a zwłaszcza w system oświaty, inicjuje potrzebę badania ich kondycji. Nie jest to zadanie 
proste, gdyż współcześnie instytucjonalny system edukacji w Polsce, niczym flagowy okręt dobrej zmiany, zdaje się dryfować po oceanie problematycznych zjawisk i procesów składających się na (bez)ład społeczny. Metafora dryfowania pozwala połączyć dwa zasadnicze zagadnienia, które są przedmiotem analizy w niniejszym opracowaniu: ewaluację edukacyjną oraz programy ukryte.

Teoretyczna perspektywa programów ukrytych, obrazowo ujmowana jako ironia skutków niezamierzonych, wydaje się dziś właściwa, aby nazwać i choć po części zrozumieć tę przedziwną podróż odsłaniającą problemy istotne dla praktykowania ewaluacji edukacyjnej. Obserwując sytuację z pewnego oddalenia, ulegamy wrażeniu, że statek spokojnie płynie, na pokładzie pracują marynarze, sternik pewnie kręci kołem sterowym według szczegółowych wskazówek kapitana, tylko wysoko na bocianim gnieździe niedostrzeżony marynarz rozpaczliwie gestykuluje, ponieważ widzi zbliżające się niebezpieczeństwo. Jednostka, która majestatycznie podąża precyzyjnie wykreślonym kursem, w istocie dryfuje w stronę niebezpiecznych skał. Żeglarze znoszeni przez prądy morskie, fale lub wiatr zdają się być obojętni na oznaki niebezpieczeństwa, zachowują się jakby byli zwodzeni urzekającym syrenim śpiewem. Posłuchał go, jak pamiętamy, także wracający do Itaki Odyseusz. Mityczny bohater jednak ocalał, nakazał bowiem swym towarzyszom w ostatnim momencie pozatykać uszy, sam zaś przywiązał się do masztu, by nie ulec nawoływaniu uwodzicielskich syren.

Nie nadwyrężając mitologicznego przesłania o „pętaniu” („przywiązywaniu”, „troczeniu” czy „sznurowaniu”) jako lekarstwie na „(o)pętanie”, należy wysycić ów subtelny teoretyczny związek między ewaluacją a programami ukrytymi. Związek ten hołubi minimalizm klasycznej proporcji „niedopowiedzianego" w obu wskazanych zagadnieniach.

\section{UKRYTY PROGRAM I EWALUACJA - TROPEM PODOBIEŃSTW I ROZBIEŻNOŚCI}

Okresowo przybierające na sile głosy krytyki pod adresem instytucji edukacyjnych na świecie zawsze rodziły pytania o rozbieżność między rzeczywistymi i postulowanymi efektami realizowanych programów, zawartych w nich celów czy deklarowanych idei. Współcześni badacze, świadomi choćby odkryć Johna Deweya, wiedzą, że realne efekty wykraczają poza te deklarowane w jawnych programach określających ład w funkcjonowaniu instytucjonalnej edukacji i zasilają teorie "programów ukrytych" (hidden curriculum). Poszukiwanie terminu, który adekwatnie odda intuicyjnie rozpoznawane przez naukowców zjawiska wymykające się systematycznej kontroli, trwało od lat 30. XX wieku. 
Ostatecznie termin hidden curriculum ukonstytuował się w latach 60. Jako twórcę pojęcia wskazuje się w literaturze przedmiotu Philipa Jacksona (w opinii Appla i Gordona) lub Edgara Friedenberga (za Bennettem i Le Comptem) ${ }^{1}$. Początków dyskusji nad ukrytym programem upatruje się też w pracy Roberta Mertona, który wyróżnił jawne i ukryte funkcje instytucji:

Ujawnianie ukrytych funkcji danego postępowania czy poglądu, który nie należy do wiedzy powszechnie dostępnej, jest istotne z tego powodu, ponieważ jest niezamierzonym i na ogół niedostrzeganym skutkiem społecznym i psychologicznym. Dopóki ludzie ograniczają się do „pewnych” skutków (to znaczy skutków jawnych), dopóty stosunkowo łatwo przychodzi im wydawanie osądów moralnych w odniesieniu do badanych norm postępowania czy poglądów².

Wyrazem wielości stanowisk teoretycznych jest bogata oferta określeń stosowanych zamiennie dla tego pojęcia, odmiennych w zależności od kontekstów kulturowych, w których powstały, takich jak: „program niejawny” (implicit curriculum) $)^{3}$, „program utajony” (latent), „niezbadany” (unstudied), uboczne skutki edukacji (by-products of schooling), pozostałości edukacji (residue of schooling), to, co szkoła czyni ludziom (what schooling does people).

Ukryty program zyskał wraz z rozwojem teorii jeszcze więcej określeń pokrewnych, raz bardziej etykietujących edukacyjną rzeczywistość, innym razem zaś skupionych na próbie jej rzetelnego wyjaśnienia ${ }^{4}$.

W języku polskim pojawiają się zamiennie następujące określenia: „program niejawny”, „program latentny”, ,program utajony”, „program nieoficjalny”, „program zamaskowany”, „pozadydaktyczne skutki szkoły”, ,drugi program szkolny”, "produkt uboczny szkoły”, „pozanaukowe elementy procesu nauczania”; w języku francuskim: le programme d'étude caché, curriculum caché, curriculum latent, curriculum implicite, éducation sous-jacente; w języku niemieckim: Naivenlehreunterricht, Heimliches Curriculum, heimlicher Lehrplan.

Istnieją też istotne różnice $\mathrm{w}$ definiowaniu istoty programów ukrytych. Jackson, kreśląc w latach 70. wizerunek szkoły naznaczonej programem ukrytym,

1 J.P. Portelli Exposing the Hidden Curriculum, "Journal of Curriculum Studies" 1993, Vol. 25(4), DOI: https://doi.org/10.1080/0022027930250404.

2 R. Merton, Teoria socjologiczna i struktura społeczna, Warszawa 1982, s. 138.

3 C. Corbleth, Beyond Hidden Curriculum?, "Journal of Curriculum Studies" 1984, Vol. 16(1), DOI: https://doi.org/10.1080/0022027840160105.

4 L.A. Sosniak, The Generalist Educator: Making a Mark on Curriculum Studies, [w:] A Life in Classrooms. Philip W. Jackson and the Practice of Education, eds. D.T. Hansen, M.E. Driscoll, R.V. Arcilla, New York-London 2007. 
napisał: „Szkoła jest miejscem, w którym uczniowie siedzą, słuchają, czekają i podnoszą dwa palce, rozmawiają, współpracują i stoją w kolejce" ${ }^{5}$. Podkreślił, że to co dzieje się w instytucji edukacyjnej każdego dnia, odzwierciedla się w doświadczeniach uczestników procesu dydaktyczno-wychowawczego, i to bez względu na jakość tych oddziaływań.

Wielokrotnie program ukryty odnoszono do organizacyjnych cech życia szkolnego i typowych dla szkoły wzorców postępowania, dostarczających podstaw, na których buduje się dyspozycje psychiczne do pełnienia ról pracownika i obywatela. Oczekiwanie w kolejce, pośpiech, handel ocenami, rywalizacja o uwagę nauczyciela czy przełożonego - to zachowania, jakich wymagają nowoczesne instytucje ${ }^{6}$.

Tak ukonstytuowane wzory instytucjonalnie akceptowanych zachowań stanowią poważną przeszkodę dla nagłych zmian wprowadzonych w trybie innowacji czy ministerialnych rozporządzeń. Na taką rafę trafiła ewaluacja edukacyjna, którą oficjalnie wprowadzono do polskiej szkoły w 2009 roku, zmieniając istotę nadzoru pedagogicznego. Jackson źródeł programów ukrytych upatruje właśnie w szerszych kontekstach środowiskowych, w których odbywa się kształcenie.

Jak przyjął Roland Meighan: „Program ukryty to termin używany do określenia tych aspektów uczenia się w szkołach, które są nieoficjalnymi, nieintencjonalnymi lub niedeklarowanymi konsekwencjami sposobu, w jaki nauczanie i uczenie się są zorganizowane i przeprowadzane w szkołach"7.

Zróżnicowane ujęcia definicyjne ${ }^{8}$ obejmują zatem refleksje nad efektami nauczania i wychowania, kompetencjami uczniów, rodzajem wiedzy implikowanej przez techniki nauczania, wzajemne relacje nauczyciela i uczniów, konotacje znaczeniowe podręczników i treści kształcenia, różnice związane z płcią

5 P. Jackson, Life in Classrooms, New York 1990, s. 4.

6 W.J. Feinberg, J.F. Soltis, Szkoła i społeczeństwo, Warszawa 2000, s. 15-25.

7 Ibidem, s. 35.

8 Na przełomie wieków nie zabrakło też polskich badaczy tego fenomenu edukacyjnego. Zob. m.in.: H. Rylke, Drugi program w szkole. Raport z badań pilotażowych, „Kwartalnik Pedagogiczny” 1984, nr 1; A. Janowski, Ukryty program polskiej szkoty, „Res Publica” 1988, nr 4; idem, Uczeń w teatrze życia szkolnego, Warszawa 1995; J. Marek, Ukryty program szkoty, „Kwartalnik Pedagogiczny” 1993, nr 1; D. Klus-Stańska, Kilka refleksji o ukrytym programie przedszkola, „Wychowanie w Przedszkolu" 1994, nr 6; D. Klus-Stańska, B. Romankiewicz, Komunikaty nauczycielek przedszkoli jako nośnik ukrytego programu, „Wychowanie w Przedszkolu” 1995, nr 3; S. Mieszalski, O przymusie i dyscyplinie w klasie szkolnej, Warszawa 1997; Z. Kwieciński, R. Kwiecińska, Ukryty program w procesie kształcenia nauczycieli w okresie szybkich zmian, „Rocznik Pedagogiczny” 1997, nr 20; H. Mizerek, Dyskursy wspótczesnej edukacji nauczycielskiej. Między tradycjonalizmem a ponowoczesnościa, Olsztyn 1999; R. Kwiecińska, Rozum czy serce? Postawy wobec zawodu nauczycielskiego, Kraków 2000; E. Siarkiewicz, Ostatni bastion, czyli jawne i ukryte wymiary pracy przedszkola, Kraków 2000; W. Żłobicki, Ukryty program w edukacji. Między manipulacją a niewiedza, Kraków 2003; J. Nowotniak, Ukryty program szkolnej rzeczywistości, Szczecin 2002. 
uczniów, ich statusem ekonomicznym, typem środowiska kulturowego. Inne aspekty programów ukrytych poddane eksploracji badawczej to np. przesłania odczytane z przestrzeni szkolnych budynków. W literaturze przedmiotu podkreśla się, że konsekwencje/efekty istnienia programu ukrytego systematycznie i trwale modyfikują zakładane rezultaty procesu edukacji.

Zdaniem Teresy Bauman, która odczytywanie programów ukrytych wiąże z potrzebą zrozumienia kulturowego kontekstu zjawiska, ich oddziaływanie buduje u różnych podmiotów edukacyjnych przekonanie, ostatecznie trudne dla nich samych do zwerbalizowania, na temat sensu edukacji. Codzienność szkolna jest utkana z zachowań, których prawie się nie zauważa i nie rozmawia się o nich, gdyż nigdy nikt nie powiedział wyraźnie, że należy ich oczekiwać. Brakuje też stosownej terminologii, aby opisać wszystkie procesy społeczne ${ }^{9}$. Pojawiają się więc sformułowania: „nieobjawiany publicznie jako zamiar”, „nieuświadomione lub nie w pełni uświadomione” "prawie intencjonalnie i całkiem nieintencjonalnie”, „nieoficjalne lub niedeklarowane”, „niejasno sprecyzowane”, „mimowolnie nauczane przez nauczyciela”.

Precyzyjne określenie znaczenia i zakresu pojęcia program ukryty jest zadaniem skomplikowanym. Podobnie zresztą jest z terminem ewaluacja. Brak należytego zrozumienia i zintegrowania historycznie uwarunkowanych procesów wysycania znaczenia ewaluacji ogranicza możliwość dotarcia do jej istoty, zwłaszcza jeżeli wychodzi się poza obszar jednej teorii czy koncepcji teoretycznej. W polskiej przestrzeni publicznej dominują debaty lokujące ewaluację w dyskursie ekonomicznym.

Wyjaśnienie znaczenia ewaluacji wymaga uwzględnienia odmienności kontekstu wiedzy, z którego określona koncepcja ewaluacji wzięła swój początek, a także różnic osadzonych w kontekstach historycznych czy w tradycjach intelektualnych dzielących Stany Zjednoczone Ameryki i Europę. Pragmatycznej genezy idei ewaluacji w USA i jej europejskich tradycji nie sposób porównywać, gdyż zupełnie inaczej rysują się w tych przypadkach związki między myśleniem, działaniem i wartościowaniem.

Kluczowe znaczenie w ewaluacji nadaje się procesowi gromadzenia wiedzy użytecznej w praktyce, będącej „podstawą do formułowania sądów na temat wartości podejmowanych działań" ${ }^{10}$. Rdzeniem pojęcia ewaluacji nadal pozostaje

9 T. Bauman, Ukryte aspekty edukacji, [w:] Kontestacje pedagogiczne, red. B. Śliwerski, Kraków 1993, s. 206.

10 H. Mizerek, Efektywna autoewaluacja w szkole - jak ja sensownie zaprojektować $i$ przeprowadzić?, [w:] Ewaluacja w nadzorze pedagogicznym. Autonomia, red. G. Mazurkiewicz, Kraków 2010, s. 21. 
kategoria jakości, wartości (value). Ewaluacja w poszukiwaniu znaczeń odnosi się do określenia zalet, wartości (worth). Podkreśla się, że w ewaluacji kluczowym przedmiotem refleksji jest wartość działania (zarówno jego efektów, jak i środków, celów i założeń).

Jedna z pierwszych definicji ewaluacji edukacyjnej, zaproponowana przez Joint Committee on Standards for Educational Evaluation ${ }^{11}$ w 1981 roku, określa ją jako systematyczne badanie wartości jakiegoś obiektu. W innej perspektywie twierdzi się nawet, że to „wartości są ewaluacjami”" ${ }^{12}$. Dewey, pisząc o wartościowaniu, wskazał na swoistą ambiwalencję towarzyszącą temu procesowi: „[...] oznacza on akt umiłowania czegoś, a także akt wydawania sądu o istocie i stopniu wartości w odniesieniu do czegoś innego"13.

Stawianie znaku równości między formułowaniem sądów wartościujących (różniących się zasadniczo od sądów o wartościach) a potocznie rozumianym ocenianiem, do którego sprowadza się ewaluację, jest poważnym uproszczeniem, a nawet błędem. Ocena może stanowić opcjonalny element (etap) procesu ewaluacji, który w wielu rodzajach ewaluacji jest w ogóle zaniechany.

Nadawanie znaczenia ewaluacji w pewnym sensie odzwierciedla więc zmiany zachodzące $\mathrm{w}$ świecie w zakresie polityki, ekonomii i kultury. Istnieje silny związek różnorodności ujęć definicyjnych z napięciami występującymi między dominującymi w naukach społecznych paradygmatami. Impulsy do rozwoju praktyk ewaluacyjnych, ale również do refleksji teoretycznej, wzajemnie się przenikają ${ }^{14}$.

Teoretykom ewaluacji i programów ukrytych często towarzyszy poczucie niemocy. Odczuwają ją też ci, którzy próbują odkodować wielowarstwową siatkę znaczeń tworzących obie kategorie, by zaprojektować działanie odnoszące się do tych teorii. Sceptyków i oponentów nie brakuje. Trudno im jednak odmówić przenikliwości, kiedy pytają, czy ujawnione w toku badania elementy nadal mają rangę ukrytych i tworzą zręby hidden curriculum, mimo że przestają być „ukryte” w potocznym znaczeniu tego słowa.

Określenie istoty „ukrytości” w kontekście programów ukrytych jest zatem jednym z kluczowych elementów w zrozumieniu fenomenu tego zjawiska. Co, przed kim, jak głęboko i w jaki sposób zostało ukryte - to bardzo ważne pytania,

11 Joint Committee on Standards for Educational Evaluation to organizacja, która powstała w 1975 roku w celu opracowywania standardów ewaluacji.

12 E.R. House, Ewaluacja jakościowa a zmiana polityki społecznej, [w:] Metody badań jakościowych, red. N.K. Denzin, Y.S. Lincoln, t. 2, Warszawa 2009, s. 609.

13 J. Dewey, Demokracja i wychowanie. Wstęp do filozofii wychowania, Warszawa 1963, s. 254.

14 Zob. poszerzoną analizę tych zagadnień w: J. Nowotniak, Ewaluacja edukacyjna. Społeczne światy ewaluatorów, Kraków 2019, s. 15-34. 
pozwalające zorientować się badaczom, jak daleko dotarli w eksploracji hidden curriculum.

Przymiotnik „ukryty” sugeruje, że coś zostało ukryte celowo przez kogoś po to, by coś zataić, nie uzewnętrznić. W drugim przypadku po prostu tak się dzieje, że to coś jest nam nieznane, gdyż z różnych powodów nie zostało dotąd odkryte i rozpoznane. Ukryty jest ten, o którym nikt nie wie, nieznany, niedający się zauważyć, niewidoczny ${ }^{15}$. W słownikach frazeologicznych ukrytość jest kojarzona głównie z celowym zatajaniem. Ukryty to niewidoczny, niezauważalny, niedostrzegalny, utajony, utajniony, zamaskowany, zakamuflowany, sekretny, potajemny.

Poczucie złożoności wyzwania wzmaga się jeszcze, kiedy uwzględni się fakt, że zjawiska edukacyjne mogą mieć różne poziomy ukrytości. Niejednakowe stopnie „głębokości” ukrycia obejmują jednostkowe przypadki ubocznych efektów nauczania w instytucjach edukacyjnych, ale też rezultaty głęboko zakorzenione w historycznie uwarunkowanych społecznych funkcjach oświaty ${ }^{16}$.

Podzielając przekonanie Gordona o istnieniu różnych poziomów ukrytości edukacyjnych, Bauman wskazuje na trzy podstawowe. Pierwszy to poziom niejawnych korelacji, będący przedmiotem zainteresowania uczonych poszukujących przyczyn różnych zjawisk i ich wzajemnych zależności. Drugi poziom ukrytości mówi o tym, jaki jest rzeczywisty świat oraz jak należy w nim postępować, aby dać sobie radę w życiu (np. w szkolnej codzienności). Ten wymiar dostrzegają i potrafią odczytać te osoby, do których jest on adresowany, ponieważ znają i rozumieją kontekst „niejawności”. Na trzecim poziomie możliwe jest ujawnianie tego, co symboliczne w edukacji, tekstów o społecznych mitach z nią związanych, a także oczekiwań i nadziei w niej pokładanych ${ }^{17}$.

Obszar wzajemnej nieokreśloności terminu jawny vs ukryty program szkoły jest więc zaskakująco rozległy, gdyż wiele zdarzeń wydaje się zbyt oczywistych, by poświęcać im chwilę refleksji; są jednak i takie, o których się nie mówi, stanowią one $w$ instytucjach edukacyjnych swoiste tabu. Uczniowie, nauczyciele i dyrektorzy szkół formułują i realizują własne przekonania dotyczące procesu nauczania - uczenia się, nawet jeśli nie są tego świadomi ${ }^{18}$; zjawiska te uwidaczniają się też w praktykowaniu ewaluacji edukacyjnej.

Na plan pierwszy wysuwa się więc potrzeba ustalenia statusu „niejawności” określonych przejawów życia szkolnego, składających się na program ukryty, jak również stanu uświadomienia jej sobie przez uczestników sytuacji i procesów

15 Słownik języka polskiego PWN, red. M. Szymczak, t. 3, Warszawa 1995, s. 549.

16 A. Janowski, Uczeń $w$ teatrze życia..., s. 51.

17 T. Bauman, op. cit., s. 204-209.

18 M.H. Dembo, Stosowana psychologia wychowawcza, Warszawa 1997, s. 38. 
edukacyjnych. Odczytywanie owej „ukrytości” jako celowej (programowej) kłóci się z główną ideą teorii programów ukrytych wyrażonej przez jej twórcę, P. Jacksona, słowami: „Istotą programu ukrytego jest to, co szkoła czyni (wpaja, uczy, daje) młodym ludziom do niej uczęszczającym, mimo że to »coś« wcale nie zostało zaplanowane" ${ }^{19}$.

Zaprezentowana w dychotomicznym układzie (intencjonalna-nieintencjonalna) „ukrytość” pozwala na wysunięcie wniosków determinujących docelowe spojrzenie na jej fenomen przez pryzmat programów ukrytych. „Ukrytość” celowa jest zaplanowana i najczęściej polega na zafałszowywaniu faktów. To co składa się na ukryty program szkoły, nie wynika z intencji, lecz znajduje odzwierciedlenie w dyspozycjach osób i układzie stosunków społecznych.

Tłumaczenie określenia hidden curriculum jako "program ukryty” budzi wiele wątpliwości. Nie chodzi tylko o puryzm językowy, lecz także o hybrydalny charakter samej nazwy, w której współwystępowanie słów „program” i „ukryty” ma charakter tautologii w kontekście znaczenia wyrażenia „program ukryty”, które używane jest do nazywania zjawisk i procesów powoływanych do życia nieświadomie, pozbawionych zamysłu celowego ukrycia czegokolwiek przed kimkolwiek. Słowa te pozostają więc w binarnej opozycji.

Pojęcie program wywodzi się z języka greckiego (prógramma), w którym było używane dla nazwania porządku dziennego bądź obwieszczenia ${ }^{20}$.

Interpretacje curriculum jako programu nauczania mieszczą się w płaszczyźnie praktyki szkolnej, nawiązując do układu treści, celów kształcenia oraz metod, jakimi można je osiągnąć ${ }^{21}$. W tradycji innych systemów oświatowych jest on również rozumiany jako lista nabywanych kompetencji szkolnych ${ }^{22}$. W Dictionnaire de l'évaluation de la recherche en éducation curriculum to ogół zaplanowanych czynności mających na celu aktywizację procesu nauczania uczenia się ${ }^{23}$. Curriculum eksponuje zatem rolę treści i zakresu treści kształcenia oraz wskazówek do ich realizacji, odnosząc je do określonego etapu rozwoju ucznia i typu szkoły.

19 A. Janowski, Uczeń $w$ teatrze życia..., s. 50.

20 W Stowniku wyrazów obcych $i$ zwrotów obcojęzycznych Władysława Kopalińskiego (Warszawa 1989, s. 414) znajdujemy takie oto wyjaśnienie terminu program: 'plan, rozkład, projekt (działań, prac, zadań, celów itp.); zarys treści i metod określonej dziedziny nauki; wyszczególnienie utworów i wykonawców spektaklu, widowiska, koncertu, punktów zabawy'.

21 Takie ujęcie zagadnienia można znaleźć w wielu tekstach źródłowych. Zob. np. W. Okoń, Wprowadzenie do dydaktyki ogólnej, Warszawa 1995; B. Śliwerski, B. Milerski, Leksykon PWN. Pedagogika, Warszawa 2000.

22 G. Mialaret, Lexique éducation, Paris 1981, s. 53.

23 G. Landsheere, Dictionnaire de l'évaluation de la recherche en éducation, Paris 1979, s. 65. 
Podstawowe ujęcia leksykalne wskazują, że "program” tworzony przez człowieka sugeruje jego intencjonalne, świadome działanie, stanowi bowiem uporządkowany zbiór, listę, zestawienie określonych informacji, czynności, instrukcji, powstały w wyniku planowania działania, o czym świadczy potrzeba przewidywania i określania następstw wydarzeń. Nie można tego powiedzieć o programie ukrytym, gdyż wtedy z całą pewnością mielibyśmy do czynienia z celowo ukrytą, świadomą aktywnością, noszącą znamiona manipulacji ${ }^{24}$.

Rzecz ma się podobnie z praktykowaniem ewaluacji edukacyjnej. Wiele zjawisk wymyka się świadomej refleksji, skłonność do uproszczeń prowadzi do zaniechań i nie ma nic wspólnego z premedytacją w działaniu. Spektakularnym przykładem jest etap powoływania kryteriów ewaluacji, którego szersza analiza zostanie przedstawiona w dalszej części niniejszego tekstu.

Uproszczenia pojawiają się też na poziomie denotacji pojęcia ewaluacja. Kontekst jest zbudowany na rusztowaniu, którego filary stanowią dwie kluczowe kategorie: accountability (odpowiedzialność) i stakeholder (interesariusz) ${ }^{25}$, skupiające uwagę na „odpowiedzialności społecznej” ewaluacji. Tłumaczenie na język polski ich znaczenia, uwzględniającego społeczno-kulturowe warunki, w których kategorie te zostały powołane do życia, pozwoliłoby zrozumieć podstawowe zadanie ewaluacji, nazywane obrazowo funkcją „adwokata społecznego", na tę chwilę przyjdzie nam jednak jeszcze poczekać ${ }^{26}$.

Reakcje na koncepcje programu ukrytego obejmują zarówno jego odrzucenie, fatalizm, odnowę kształcenia, jak i idee deskolaryzacji. Podobna skala emocji towarzyszy dociekaniu istoty ewaluacji oraz możliwości adaptacji praktyki ewaluacyjnej w warunkach polskich.

Program ukryty i ewaluacja są więc szczególnymi przykładami pojęć matrycowych $^{27}$, będących wysoce złożoną jednostką informacyjną, w której stałość współwystępowania cech wymaga za każdym razem osobnego komentarza. Jan Trzebiński odróżnia pojęcia matrycowe od pojęć naturalnych. Te pierwsze tworzone są sztucznie, a ich treścią jest zespół cech odróżniających założoną klasę

24 W kontekście rozważań o istocie hidden curriculum związek frazeologiczny wyrazów „program” i „ukryty” nosi znamiona wyrażenia oksymoronicznego. Obejmuje bowiem dwa wyrazy, których znaczenie można odczytać jako opozycyjne. Metaforyczny związek obu słów nie jest jednak celem tego połączenia, stąd trudno w pełni prawomocnie posługiwać się tu określeniem „oksymoron” w sensie sugerowanym przez twórców Stownika terminów literackich (red. J. Sławiński, Warszawa 1988, s. 325).

25 Teoria interesariuszy sformułowana przez R. Edwarda Freemana w latach 80. XX wieku ma obecnie wiele zróżnicowanych modeli i jest uznawana za fundament analizy społecznej odpowiedzialności biznesu.

26 H. Mizerek, Ewaluacja edukacyjna. Interdyskursywne dialogi i konfrontacje, Kraków 2017.

27 J. Trzebiński, Twórczość a struktura pojęć, Warszawa 1981, s. 11-12. 
obiektów od innych obiektów i zarazem charakteryzujących wszelkie obiekty tej klasy. Idea zaproponowanego tu podziału wiąże się z istnieniem tzw. rdzenia pojęciowego oraz z dopuszczalną wielkością jego transformacji ${ }^{28}$.

Nadmierne transformacje, nadbudowujące kolejne znaczenia, ale i te upraszczające, uszczuplające rdzenie pojęciowe, mogą uniemożliwić zrozumienie istoty zjawisk nazywanych danym terminem.

Wieloznaczność pojęć program ukryty oraz ewaluacja wynika ze złożoności nazywanej przez nie grupy zjawisk. Niejednoznaczność terminologiczną można też postrzegać jako immanentną cechę wiedzy o fragmencie rzeczywistości poddawanym refleksji przy użyciu teorii programów ukrytych czy ewaluacji. Konstatacja ta wydaje się znajdować potwierdzenie w sposobie projektowania i realizacji działań odwołujących się do obu teorii.

Trudność tworzenia spójnej definicji ukrytych programów wynika również z faktu, że nie jest łatwo wyizolować to zjawisko z licznych kontekstów, które je współtworzą. Ewaluacja bez kontekstu, który dookreśla jej charakter, także przestaje być czytelna. Programy ukryte same są swoistym kontekstem edukacji i tylko poprzez analizę i opis zjawisk, którym towarzyszą, można oddać ich sens.

Karkołomnym, choć niezwykle ważnym, zadaniem wydaje się próba połączenia ewaluacji i programów ukrytych w tezę o istnieniu ukrytych programów ewaluacji. Zabieg ten wprawia obie kategorie w teoretyczny ruch.

Powołanie do życia zagadnienia określanego jako „ukryte programy ewaluacji edukacyjnej” dla wyjaśniania zjawisk wielowarstwowej rzeczywistości edukacyjnej jest więc arcyciekawym zadaniem dla teoretyków i praktyków oddanych sprawie edukacji, ale wymaga odwagi i siły na miarę bohaterów Marvel Cinematic Universe czy „endemicznej Siłaczki”.

\section{PRAKTYKA POZA TEORIĄ I POZA REFLEKSJĄ - UKRYTY WYMIAR PROCESU EWALUOWANIA}

Wprowadzona w 2009 roku zmiana w sprawowaniu nadzoru pedagogicznego w Polsce była przedsięwzięciem noszącym znamiona projektu cywilizacyjnego, zapowiadającym możliwość autonomicznego działania nauczycieli. Podstawą projektu było rozdzielenie trzech zadań nadzorczych: ewaluacji, wspomagania podmiotów edukacji w danej placówce oraz prowadzenia kontroli (do tej pory były to funkcje: diagnostyczna, kontrolna i wspierająca). Jednym z kluczowych elementów zmiany stały się sformułowane przez państwo wymagania wobec szkół i placówek. Fundamentem nowej idei było wprowadzenie ewaluacji. Proces

28 J. Nowotniak, Ukryty program... 
zewnętrznej ewaluacji powierzono zespołowi wizytatorów do spraw ewaluacji, który gromadził dane o poziomie spełniania wymagań przez placówki oświatowe. Dla zrównoważenia potencjalnej niebezpiecznej skłonności do instrumentalizacji i komercjalizacji wiedzy (co mogłoby się wiązać z efektami ewaluacji zewnętrznej) wprowadzono ewaluację wewnętrzną, prowadzoną przez zespoły ewaluacyjne w szkołach, złożone z ich pracowników.

Celem reformy było usprawnienie procesu decyzyjnego zarówno na poziomie pojedynczej placówki, jak i w ramach polityki oświatowej państwa poprzez dostarczanie szerokiego strumienia bieżących informacji na temat funkcjonowania całego systemu edukacyjnego ${ }^{29}$.

Ewaluację wprowadzono do nadzoru pedagogicznego już w 2004 roku. Wówczas ujmowano ją jako „ocenę przydatności i skuteczności podejmowanych działań dydaktycznych, wychowawczych i opiekuńczych w odniesieniu do założonych celów, służących doskonaleniu tych działań”30.

Zaproponowana idea ewaluacji wewnętrznej, filar systemu ewaluacji oświaty SEO, zakładała wykorzystanie ewaluacji rozwojowej ${ }^{31}$, dialogicznej, bazującej na zasadach odwołujących się do teorii, która pozwoli zrozumieć zachodzące zmiany już w trakcie trwania procesu ewaluowania.

Egon G. Guba i Yvonna S. Lincoln takie podejście w ewaluacji nazwali ewaluacją dialogiczno-konstruktywistyczną (responsive constructivist evaluation). Paradygmat konstruktywistyczny w nauce zrewolucjonizował myślenie o ewaluacji i ujawnił jej dialogiczny potencjał. Pojęcie „dialogiczny” (responsive) kładzie nacisk na negocjacyjny sposób decydowania o parametrach ewaluacji. Autorzy Fourth Generation Evaluation wybrali nazwę „konstruktywistyczny”, akcentując, że można go nazywać również „wyjaśniającym” (interpretive) ${ }^{32}$.

29 Intensyfikacja obecności tych idei w przestrzeni publicznej nastąpiła z chwilą powstania Systemu Ewaluacji Oświaty (SEO) oraz realizacji „Programu wzmocnienia efektywności systemu nadzoru pedagogicznego i oceny jakości pracy szkoły" przez Uniwersytet Jagielloński w partnerstwie z MEN oraz Ośrodkiem Rozwoju Edukacji (ORE) i Erą Ewaluacji. W ramach SEO podjęto również zadanie szkolenia wizytatorów, nauczycieli i dyrektorów w dziedzinie metodologii i praktyki prowadzenia ewaluacji zewnętrznej i ewaluacji wewnętrznej.

30 Rozporządzenie Ministra Edukacji Narodowej i Sportu z dnia 23 kwietnia 2004 roku w sprawie szczegółowych zasad sprawowania nadzoru pedagogicznego, wykazu stanowisk wymagających kwalifikacji pedagogicznych, kwalifikacji niezbędnych do sprawowania nadzoru pedagogicznego, a także kwalifikacji osób, którym można zlecać prowadzenie badań i opracowywanie ekspertyz (Dz.U. nr 89, poz. 845).

31 S. Jaskuła, Ewaluacja rozwojowa jako wyzwanie wspótczesnego systemu edukacji, „Zarządzanie Publiczne" 2012, nr 3.

32 E.G. Guba, Y.S. Lincoln, Fourth Generation Evaluation, London 1989, s. 38. 
W latach 70. w Wielkiej Brytanii na Uniwersytecie w Norwich (UEA) powstało Centre for Applied Research in Education (CARE), skupiające znakomitych badaczy inicjujących międzynarodowe projekty badawcze (Barry MacDonald, John Elliott, Nigel Norris, Rob Walker, John Schostak). Zaczęto w nim rozwijać koncepcję ewaluacji demokratycznej.

Jakościowe nurty ewaluacji rozwijano również w School of Education na Uniwersytecie w Southampton od początku jego istnienia. Tu warto odnotować działania podejmowane przez Helen Simons z zespołem. To z tym środowiskiem naukowców należy wiązać powstanie idei ewaluacji dialogicznej i demokratycznej oraz autoewaluacji.

W ramach ontologicznych, epistemologicznych i metodologicznych założeń konstruktywizmu funkcjonowało wiele rodzajów ewaluacji. W obrębie ewaluacji dialogicznej najbardziej znaczące modele to: ewaluacja responsywna (responsive evaluation), deliberatywna demokratyczna ewaluacja (deliberative democratic evaluation), ewaluacja inkluzywna (inclusive evaluation), ewaluacja upełnomocniająca (empowerment evaluation).

Kluczowe znaczenie dla rozwoju tego paradygmatu mają prace Roberta Stake'a, zwłaszcza teoretyczny model responsive evaluation. Do podstawowych wyzwań postawionych przed ewaluatorem należało wyczulenie na zróżnicowanie kulturowe oraz związane z nim potrzeby i doświadczenia uczestników wynikające $\mathrm{z}$ kontekstu społecznego i historycznego, w jakim realizowano program poddany ewaluacji ${ }^{33}$. Ewaluator w istocie był „facylitatorem dialogu”. Podkreślona została animacyjna i edukacyjna rola ewaluacji. Stake opracował metodologię badania wartości, czyli strategię studium przypadku (case study) ${ }^{34}$, stanowiącą idiograficzny model wyjaśniania.

Osadzenie od połowy lat 80. ewaluacji edukacyjnych w konstruktywizmie przyniosło rozkwit ewaluacji rozwojowych i poznawczych, których głównym przedmiotem uczyniono przebieg procesów edukacyjnych, a nie jedynie ich efektów. Dialogicznie ustalano cele, kryteria i metody realizacji ewaluacji, ewaluatora z kolei zwolniono z potrzeby poszukiwania „jedynej obiektywnej prawdy", podkreślając, że raport nie jest tylko własnością zamawiającego. Proces ogłaszania wyników i formułowania rekomendacji w założeniu miał być debatą nad potrzebą podjęcia właściwych decyzji. Tak zaplanowane i przeprowadzane

33 Jak stwierdził Stake: „[...] celem ewaluacji jest odkrywanie zwyczajnych sposobów postrzegania przez ludzi jakości i wartości" (R. Stake, T.A. Abma, Responsive evaluation, [w:] Encyclopedia of Evaluation, New Delhi 2005, s. 377).

34 R. Stake, The Art of Case Study Research, London 1995; idem, Studium przypadku, [w:] Ewaluacja w edukacji, red. L. Korporowicz, Warszawa 1997. 
ewaluacje uruchomiły animacyjne funkcje badania ewaluacyjnego. W szerszym kontekście zaś zainicjowały proces zmiany kulturowej, stymulujący różne postacie ewaluacyjnego dyskursu, a poza tym uwolniły potencjały społeczne, kulturowe i ludzkie, będące integralną konsekwencją całego działania ${ }^{35}$.

Tak pomyślana ewaluacja jest wykorzystywana do upełnomocniania podmiotów zaangażowanych w jej proces. Wyraźnie trzeba zaznaczyć, że ewaluacje dialogiczne, demokratyczne, wykorzystujące metodologiczną strategię badawczą znaną jako studium przypadku (case study), zaczęto stosować w polskiej edukacji w latach 90. XX wieku w trakcie realizacji programów TERM i SMART ${ }^{36}$. Praktyki ewaluacyjne istniały zatem w Polsce przed rokiem 200937. Początek lat 90. ubiegłego stulecia to moment wprowadzenia terminu ewaluacja w aspekcie refleksji nad potrzebą rozwijania ewaluacji jako dyscypliny akademickiej.

Analizując programy ukryte ewaluacji wewnętrznej, warto poświęcić chwilę samemu terminowi ewaluacja wewnętrzna, aby móc oszacować, co wydarzyło się „poza teorią”. Okazuje się, że już na poziomie sposobu nazywania rodzajów ewaluacji uruchomił się znamienny dla programów ukrytych proces wypełniania nazwy znaczeniami o znamionach etykiet. Dostrzegł go Henryk Mizerek, który dowodzi, że nie jest to najszczęśliwsze określenie z tej choćby przyczyny, że jego rozumienie nie jest zgodne z tym, co w literaturze przedmiotu uznaje się za ewaluację wewnętrzną (internal evaluation). Zamysł reformatorów odnosi się (czy też oddaje sens) do innego terminu - autoewalucja (self-evaluation) ${ }^{38}$. Ewaluacja wewnętrzna jest prowadzona w instytucji na jej potrzeby w ramach specjalnie powołanej do tego komórki. Otwiera ona drogę do zatrudniania specjalistów z zewnątrz, co zresztą wydarzyło się w polskich szkołach.

Autoewaluacją powinny się zajmować osoby (w tym przypadku nauczyciele, pedagodzy) będące badaczami własnej praktyki. Podejmują się one pełnienia dwóch ról jednocześnie: nauczania i prowadzenia badań, bez wymogu profesjonalnego przygotowania do prowadzenia ewaluacji. Za Simons można powtórzyć,

35 L. Korporowicz, Interakcyjna misja ewaluacji, [w:] Ewaluacja w nadzorze pedagogicznym. Konteksty, red. G. Mazurkiewicz, Kraków 2010.

36 H. Mizerek, Evaluation in Education in Poland: Initial Experience, [w:] 15-lecie Katedry UNESCO UWM w Olsztynie, red. J. Górniewicz, Olsztyn 2006.

37 L. Korporowicz, Zmienne losy polskiej ewaluacji. Pomiędzy nadzieja, animacja i konfuzja, [w:] Ewaluacja w edukacji. Koncepcje, metody, perspektywy, red. B. Niemierko, K. Szmigiel, Kraków 2011; idem, Społeczna etyka ewaluacji, „Teraźniejszość - Człowiek - Edukacja” 2013, nr 4, s. 35-45.

38 J.E. MacBeath, A. McGlynn, Self-Evaluation: What's In It for Schools?, London 2002; S. Speer, Peer Evaluation and Its Blurred Boundaries: Results from a Meta-evaluation in Initial Vocational Education and Training, "Evaluation" 2010, Vol. 16(4), DOI: https://doi. org/10.1177/1356389010382265. 
że ewaluacja to zaproszenie do rozwoju ${ }^{39}$. Nagminne używanie terminu ewaluacja wewnętrzna $\mathrm{w}$ odniesieniu do podejmowanych przez nauczycieli działań ewaluacyjnych stwarza zdaniem Mizerka niebezpieczeństwo zbiurokratyzowania jej procedur ${ }^{40}$.

Kluczowym elementem planowania ewaluacji jest etap formułowania kryteriów. Korespondujące z tytułowym wyzwaniem niniejszego tekstu pytanie brzmi: Jakie, jak głęboko, w jaki sposób i za czym ukryte są dla ewaluatorów kryteria ewaluacji?

Fundamentalna jest tu świadomość faktu, że dobór kryteriów ewaluacji ujawnia ideologię, z którą identyfikuje się ewaluator. Poważnym problemem na tym etapie jest mała świadomość u ewaluatorów potrzeby budowania ideologicznego zaplecza własnej praktyki zawodowej. Wtóruje temu niska frekwencja dyskusji prowadzonych w murach polskiej szkoły na temat celów edukacji zogniskowanych wokół zagadnienia wartości.

To poziom wiedzy ewaluatorów o rodzajach kryteriów i znaczeniu ich świadomego doboru warunkuje wybór rodzaju ewaluacji, która może przybierać skrajnie odmienne formy. Rezultaty działania bada ewaluacja konkluzywna, sięgająca po tzw. obiektywne wartości. Jej kryteria to najczęściej: zgodność efektów z przyjętymi celami, trwałość rezultatów, kosztochłonność itp. Ewaluacja, która dostarcza wiedzy na temat wszystkich aspektów podjętych aktywności ewaluacyjnych, ma postać ewaluacji formatywnej ${ }^{41}$. Ewaluacje poznawcze będą zmierzać do dostarczenia wiedzy umożliwiającej wgląd w takie zagadnienia, jak uwarunkowania efektów kształcenia, lecz także etos, kultura czy klimat szkoły.

Brak zrozumienia dla istoty tego etapu lokuje ewaluację w aksjologicznej próżni - wszystko jest wszystkim, nic jest niczym. Nieliczni nauczyciele unikali tej pułapki, kierując się przesłanką, że źródła kryteriów kryją się w wymaganiach państwa wobec szkół. Trudno tu jednak mówić o autoewaluacji, ponieważ znów sięgnięto po wzornik, by dobrać właściwy kolor. Etap świadomego przyjęcia kryteriów rzutuje na jakość działań w następnych etapach ewaluacji, a jednym z nich jest dobranie metod badawczych i procedur analizowania danych.

Wiedza, którą nabywają szkolne zespoły ewaluacyjne w toku własnych praktyk, idąc często po omacku, jest uczeniem się ewaluacji implicite. Bezsprzecznie potrzebne jest więc przygotowanie nauczycieli do nowych zadań również poprzez poszukiwanie i rozpowszechnianie teorii pozwalających wyjaśnić sens

39 H. Simons, Getting to Know Schools in a Democracy. A Politics and Process of Evaluation, London 1987.

40 H. Mizerek, Efektywna autoewaluacja..., s. 20-24.

41 E. Babbie, Badania społeczne w praktyce, Warszawa 2006, s. 394. 
projektowanej zmiany, ale i uniknięcie podstawowych zagrożeń wynikających z rosnących wpływów ideologii neoliberalnej w sferze edukacji.

Refleksja ewaluacyjna nad działaniem w edukacji ma specyficzny charakter, „można bez ryzyka nadmiernych uproszczeń założyć, że istota ewaluacji, jej sedno, sprowadza się do refleksji nad wartością działań, które podejmowano w przeszłości, prowadzi się aktualnie lub zamierza się podjąć w przyszłości”².

Długo jednak w obszarze nauk o wychowaniu utożsamiano ją z „praktycznymi badaniami oceniającymi” ${ }^{43}$, czego skutki widoczne są dziś ze wzmożoną siłą. Współcześnie jest to wykładnia idei i celów ewaluacji strategicznych i operacyjnych, praktykowanych w administracji państwowej, zmierzających do zobrazowania efektów interwencji publicznych. Jej przedmiotem jest analiza i ocena trafności ogólnych kierunków interwencji wyznaczonych na etapie realizacji określonych celów strategicznych. Działania składające się na tego typu postępowanie mają swoje źródła w racjonalnej teorii działania.

Zupełnie inny jest status pożądanych dziś ewaluacji edukacyjnych, odwołujących się do perspektywy progresywnej i koncepcji doświadczenia pojmowanego relacyjnie ${ }^{44}$, rozwijanej już przez Deweya.

Wszelkie generalizacje, jako wnioski końcowe, nie są uprawnione, choć dekada własnych studiów empirycznych usprawiedliwia potrzebę zarysowania choć konturu obrazu. Zmianie koncepcji nadzoru pedagogicznego towarzyszył rozmach na skalę w Polsce nieznaną. Właściwie był to pomysł (wizja) na gruntowną przebudowę wszystkiego na nowo, zgodnie z wytyczonym planem, kolektywnie, realizowaną z udziałem zaangażowanych w nią ludzi z przekonaniem powtarzających nauczycielom: W końcu możecie zrobić to, czego nigdy nie robiliście. Udało się to nauczycielom, którzy byli na to wyzwanie gotowi, czyli silnym doświadczeniami wyniesionymi z codziennego poszukiwania odpowiedzi na podstawowe pytanie refleksyjnego praktyka: Jak mi dzisiaj poszło?

Ewaluacja jako praktyka społeczna w znaczącej mierze jest odseparowana od ewaluacji rozumianej jako dyscyplina akademicka. Znamiennym tego przykładem było niewielkie zainteresowanie środowisk akademickich ${ }^{45}$ udzielaniem wsparcia

42 H. Mizerek, Efektywna autoewaluacja..., s. 29.

43 K. Konarzewski, Jak uprawiać badania oświatowe. Metodologia praktyczna, Warszawa 2000, s. 13.

44 J. Dewey, op. cit.

45 Poza naukowcami zaangażowanymi w realizację „Programu wzmocnienia efektywności systemu nadzoru pedagogicznego i oceny jakości pracy szkoły”, który był projektem systemowym III Priorytetu Programu Operacyjnego Kapitał Ludzki „Wysoka jakość systemu oświaty”. W latach 2010-2015 realizowano w nim działanie „Modernizacja systemu nadzoru pedagogicznego". Projekt był prowadzony przez Ośrodek Rozwoju Edukacji w partnerstwie z Uniwersytetem Jagiellońskim i Erą Ewaluacji. 
naukowego procesowi wprowadzenia do polskiego systemu oświaty ewaluacji zewnętrznej i wewnętrznej po 2009 roku. Słowami Eugenii Potulickiej tak można ująć zaistniały stan rzeczy: „Presja bez wsparcia prowadzi do oporu i alienacji, wsparcie bez presji prowadzi do dryfowania lub marnotrawienia zasobów"46.

Dla porządku należy przypomnieć, że w literaturze przedmiotu rozdziela się zagadnienie stosowanych badań ewaluacyjnych (evaluation research, research utilization, applied research) od ewaluacji (evaluation utilization, evaluation use). Badania ewaluacyjne stanowią bardzo zróżnicowany, mało spójny wewnętrznie nurt stosowanych badań społecznych na świecie. Z pewnością ewaluacje edukacyjne mogłyby wykorzystać możliwości, jakie dają stosowane badania naukowe, lecz ewaluacja jako praktyka społeczna w edukacji w dużej mierze jest odseparowana od ewaluacji rozumianej jako dyscyplina akademicka. Reforma nadzoru pedagogicznego w Polsce odsłoniła różne wymiary tego problemu, w tym problemy wewnątrz akademii.

Dokonując eksplikacji pojęcia program ukryty, Zbigniew Kwieciński w kontekście szkoły pisał: „[...] demaskowana jest jako »ukryty program « odtwarzania stosunków dominacji, hierarchii i legitymizowania nierówności, nienawiści i wojny" ${ }^{\prime 7}$. Niespełna pół wieku później podpisanie się pod tymi słowami - także przez akademików odnoszących je do sytuacji szkolnictwa wyższego - wydaje się niepokojąco oczywistą potrzebą.

\section{NULL CURRICULUM - NOWY POCZĄTEK CZY KRES EWALUACJI EDUKACYJNEJ?}

Krytyczny ogląd praktyki ewaluacyjnej w polskiej szkole, odnoszony do realiów funkcjonowania uniwersytetu, dotyczy dwóch problemów: kształcenia pedagogów i nauczycieli oraz ewaluacji wyników kształcenia i działalności naukowej jednostek naukowych. Oba są silnie sprzężone z dyskursami w obrębie samej pedagogiki, generowanymi wewnątrz każdej akademii.

Kryzys oświeceniowego modelu nauki i wiedzy oraz komercjalizacja dwóch podstawowych funkcji uczelni (badawczej i kształcącej) prowadzą do ukrytej detronizacji statusu wiedzy akademickiej oraz roli i funkcji uniwersytetu w kształtowaniu ładu społecznego ${ }^{48}$.

46 E. Potulicka, Paradygmat zmiany edukacyjnej Michaela Fullana, [w:] Szkice z teorii i praktyki zmiany oświatowej, red. E. Potulicka, Poznań 2001, s. 28.

47 Z. Kwieciński, Socjopatologia edukacji, Olecko 1995, s. 123.

48 Wskazane tendencje i kierunki zmian uniwersytetów Zbyszko Melosik w książce Uniwersytet $i$ społeczeństwo. Dyskursy wolności, wiedzy i władzy (Kraków 2009) ubiera w metaforę 
Wiedza, proces edukacji i wykształcenie stają się wartościowe jedynie wtedy, gdy są instrumentalnie użyteczne. Uniwersytet jako inwestycja państwa w rozwój ekonomiczny nie jest zainteresowany powstrzymywaniem dewaluacji wartości tradycyjnie wiązanych z uczelnią, a nawet refleksją nad nimi. W tej zmienionej perspektywie aksjologicznej nowy model absolwenta zakłada, że staje się on specjalistą i pragmatykiem oceniającym mechanizmy rynkowe pod kątem własnego zysku. Wartościowanie rzeczywistości społecznej (swoisty fundament ewaluacji) nie mieści się w tym modelu funkcjonowania.

Mamy chyba do czynienia z sytuacją polegającą na wprowadzeniu w życie pewnej pedagogicznej idei - ewaluacji edukacyjnej, która jest uważana za ważną, ale jej realizacji towarzyszy ukryte przekonanie, że jest to niemożliwe. Słowami Marii Dudzikowej można ten paradoks wyrazić następująco - dążymy do budowania kapitału społecznego opartego na relacjach i promowaniu wartości wspólnoty oraz zaangażowania w społeczne dobro, ale realizujemy procedury sprzyjające biurokratyzacji i ograniczające ten kapitał ${ }^{49}$.

Bolesną świadomość tego faktu mają ci akademicy, którzy dostrajają organizację studiów do kategorii studentów, którzy nie spełniają minimalnych warunków wejściowych. Zaniżanie kryteriów osiągnięć sprawia, że niemal wszyscy studenci je spełniają. Zasadniczym powodem jest obniżenie wymagań uczelni wyższych, które jako jednostki komercyjne zainteresowane są intensyfikowaniem korzyści ekonomicznych. Efektem ubocznym umasowienia edukacji jest brak krytycyzmu absolwentów, którzy w toku studiów nie dostają rzetelnych informacji zwrotnych o własnych osiągnięciach; co więcej, przestają być zdolni do autoewaluacji, także podejmując aktywność zawodową:

Niezależnie od tego, jak światła jest kadra nauczycielska, jak bardzo postępowy jest program i jak bardzo zorientowana na społeczność jest szkoła, do uczniów dociera coś, o czym nigdy nie mówi się na lekcjach [...]. Uczniowie podchwytują pewne podejście do życia i pewną postawę w uczeniu się ${ }^{50}$.

W urynkowionej ofercie programowej brakuje miejsca na rozwijanie refleksyjności, absolwent pedagog czy nauczyciel to specjalista elastycznie dostosowujący się do oczekiwań pracodawcy. Bolesna świadomość tego mechanizmu

metamorfozy świątyni wiedzy w przedsiębiorstwo dostarczające usługi i produkty (w postaci kształcenia, wyników badań, absolwentów określonego typu).

49 M. Dudzikowa, Szkoła jako przestrzeń, w której i poprzez którą tworzony jest kapitat spoteczny? Suplement do „Erozji kapitału..., [w:] eadem, Kapitat społeczny w szkołach różnego szczebla. Diagnoza i uwarunkowania, t. 2, Kraków 2011.

50 R. Meighan, Socjologia edukacji, Toruń 1993, s. 71. 
i nagląca potrzeba zamknięcia budżetu uczelni sprawiają, że nauczyciele akademiccy oddają ewaluację specjalnie powoływanym jednostkom uniwersyteckim zajmującym się jakością kształcenia, co koresponduje z ideą powierzenia zarządzania uniwersytetami menedżerom stojącym na straży zwiększania dostępności i jakości edukacji przy równoczesnym zmniejszeniu jej kosztów.

Przysłowiowe „wyjście na plus” lub choćby na zero (czyli bez strat) przywodzi inną kategorię powiązaną z hidden curriculum, a mianowicie null curriculum $^{51}$ (wyzerowanego programu) wprowadzoną przez Elliota W. Eisnera ${ }^{52}$. Owa koncepcja zmienia optykę badania szkoły, jest zachętą do poznania nieznanego - tego, czego się w szkole nie naucza, co wyłącza się z doświadczeń jednostkowych i zbiorowych podmiotów edukacji na zasadzie nieświadomego zaniechania. Nauczyciele zazwyczaj nie są świadomi tych pominięć, a tym bardziej ich konsekwencji. Mechanizmy wyłączania dotyczą różnych rodzajów procesów intelektualnych, klasycznym przykładem jest myślenie twórcze.

Problem dotyczy np. uświadomienia uczniom w toku edukacji potrzeby ewaluowania swojej wielostronnej aktywności. Wyłączenia te ustanawiają trwałe bariery dla możliwości planowania i realizacji samokształcenia czy samodoskonalenia w ogóle, ograniczając tym samym ich perspektywy myślowe. Nieuwzględnianie treści nauczania, pomijanie całych bloków problemowych czy poszczególnych jednostek informacji znajduje odzwierciedlenie w kształtowaniu tożsamości osobowej, kulturowej i społecznej uczniów/studentów.

Są to też skutki okrojonych programów kształcenia nauczycieli. Spektakularnym przykładem funkcjonowania null curriculum jest projekt rozporządzenia Ministra Nauki i Szkolnictwa Wyższego z dnia 19 kwietnia 2019 roku w sprawie standardu kształcenia przygotowującego do wykonywania zawodu nauczyciela, a w szczególności załącznik nr 2 tego rozporządzenia, obejmujący Standard kształcenia przygotowującego do wykonywania zawodu nauczyciela przedszkola i edukacji wczesnoszkolnej (klasy I-III szkoły podstawowej).

W opinii przekazanej Ministerstwu Nauki i Szkolnictwa Wyższego przez wiceprzewodniczącą Komitetu Nauk Pedagogicznych PAN profesor Dorotę Klus-Stańską zostały uwypuklone mechanizmy selekcji i eliminacji pewnych opcji własnej orientacji nauczycieli w polu udostępnionej im w toku kształcenia wiedzy, jej interpretacji i możliwej krytyki. Spektakularnym przykładem jest

51 Koncepcję „wyzerowanego programu” (null curriculum) odkryłam, poruszając się w obrębie własnych studiów empirycznych nad ukrytym programem szkoły (szczecińskich liceów 1999-2001). Profesor Z. Kwieciński wygłosił znakomity wykład na ten temat podczas uroczystości nadania mu godności doktora honoris causa Uniwersytetu Opolskiego w dniu 22 kwietnia 2004 roku.

52 E.W. Eisner, The Educational Imagination, New York 1979. 
„wyzerowanie” znaczenia wczesnej edukacji (określanej żłobkową, bo przypadającą na trzy pierwsze lata życia dziecka). Czyżby wynikało to z zaniechań, których doświadczyli autorzy dokumentu w swojej edukacji na skutek działania programów ukrytych lub wyzerowanych?

Ewidentnie brak w tym projekcie miejsca na rozwijanie sztuki ewaluowania i autoewaluowania własnej praktyki zawodowej przez przyszłych nauczycieli i pedagogów, a to przecież stanowi fundament bycia refleksyjnym praktykiem, co jest jednym z najważniejszych buforów „analfabetyzmu krytycznego” 53 .

Zagadnienie ewaluacji edukacyjnej na świecie systematycznie zyskuje na znaczeniu, zwiększając wpływ na działania podejmowane w polityce publicznej. Bezpośrednim bodźcem jest wzrastający nacisk na efektywność, trafność alokowania środków i odpowiedzialność działań instytucji publicznych, także w systemie oświaty. Pojmowanie jej znaczenia jest jednak znacznie szersze, gdyż jest łączone z potrzebą budowania strategii rozwoju w różnych dziedzinach życia społecznego oraz z zabezpieczaniem interesu publicznego wielu zróżnicowanych grup społecznych.

Skutki „wyzerowania” refleksji na temat ewaluacji w naszym kraju oraz zaniechanie jej praktykowania w odniesieniu do stuletniej historii teorii ewaluacji można by mnożyć. Najbardziej niebezpieczne jest jednak porzucenie myślenia na rzecz ideologii. Kategorie bliskoznaczne dla „wyzerowania” to „brak”, „kres”, „pustka”. Jest i „początek”, który pozwala z nadzieją patrzeć w przyszłość. Tylko czy naprawdę musimy i mamy czas na to, aby znów zaczynać od początku?

\section{BIBLIOGRAFIA}

Babbie E., Badania społeczne w praktyce, Warszawa 2006.

Bauman T., Ukryte aspekty edukacji, [w:] Kontestacje pedagogiczne, red. B. Śliwerski, Kraków 1993.

Corbleth C., Beyond Hidden Curriculum?, "Journal of Curriculum Studies” 1984, Vol. 16(1), DOI: https://doi.org/10.1080/0022027840160105.

Dembo M.H., Stosowana psychologia wychowawcza, Warszawa 1997.

Dewey J., Demokracja $i$ wychowanie. Wstęp do filozofii wychowania, Warszawa 1963.

Dudzikowa M., Szkoła jako przestrzeń, w której i poprzez która tworzony jest kapitat społeczny? Suplement do „Erozji kapitału..., [w:] eadem, Kapitat społeczny w szkołach różnego szczebla. Diagnoza i uwarunkowania, t. 2, Kraków 2011.

Eisner E.W., The Educational Imagination, New York 1979.

Feinberg W.J., Soltis J.F., Szkoła i społeczeństwo, Warszawa 2000.

Guba E.G., Lincoln Y.S., Fourth Generation Evaluation, London 1989.

53 A. Nalaskowski, Nauczyciele z prowincji u progu reformy edukacji, Toruń 1998. 
House E.R., Ewaluacja jakościowa a zmiana polityki społecznej, [w:] Metody badań jakościowych, red. N.K. Denzin, Y.S. Lincoln, t. 2, Warszawa 2009.

Jackson P., Life in Classrooms, New York 1990.

Janowski A., Uczeń w teatrze życia szkolnego, Warszawa 1995.

Janowski A., Ukryty program polskiej szkoty, „Res Publica” 1988, nr 4.

Jaskuła S., Ewaluacja rozwojowa jako wyzwanie wspótczesnego systemu edukacji, „Zarządzanie Publiczne” 2012, nr 3.

Klus-Stańska D., Kilka refleksji o ukrytym programie przedszkola, „Wychowanie w Przedszkolu" 1994, nr 6.

Klus-Stańska D., Romankiewicz B., Komunikaty nauczycielek przedszkoli jako nośnik ukrytego programu, „Wychowanie w Przedszkolu” 1995, nr 3.

Konarzewski K., Jak uprawiać badania oświatowe. Metodologia praktyczna, Warszawa 2000.

Kopaliński W., Stownik wyrazów obcych i zwrotów obcojęzycznych, Warszawa 1989.

Korporowicz L., Interakcyjna misja ewaluacji, [w:] Ewaluacja w nadzorze pedagogicznym. Konteksty, red. G. Mazurkiewicz, Kraków 2010.

Korporowicz L., Społeczna etyka ewaluacji, „Teraźniejszość - Człowiek - Edukacja” 2013, nr 4.

Korporowicz L., Zmienne losy polskiej ewaluacji. Pomiędzy nadzieją, animacją i konfuzja, [w:] Ewaluacja w edukacji. Koncepcje, metody, perspektywy, red. B. Niemierko, K. Szmigiel, Kraków 2011.

Kwiecińska R., Rozum czy serce? Postawy wobec zawodu nauczycielskiego, Kraków 2000.

Kwieciński Z., Socjopatologia edukacji, Olecko 1995.

Kwieciński Z., Kwiecińska R., Ukryty program w procesie ksztatcenia nauczycieli w okresie szybkich zmian, „Rocznik Pedagogiczny” 1997, nr 20.

Landsheere G., Dictionnaire de l'évaluation de la recherche en éducation, Paris 1979.

MacBeath J.E., McGlynn A., Self-Evaluation: What's In It for Schools?, London 2002.

Marek J., Ukryty program szkoty, „Kwartalnik Pedagogiczny” 1993, nr 1.

Meighan R., Socjologia edukacji, Toruń 1993.

Melosik Z., Uniwersytet $i$ społeczeństwo. Dyskursy wolności, wiedzy i władzy, Kraków 2009.

Merton R., Teoria socjologiczna i struktura społeczna, Warszawa 1982.

Mialaret G., Lexique éducation, Paris 1981.

Mieszalski S., O przymusie i dyscyplinie w klasie szkolnej, Warszawa 1997.

Mizerek H., Dyskursy wspótczesnej edukacji nauczycielskiej. Między tradycjonalizmem a ponowoczesnościa, Olsztyn 1999.

Mizerek H., Efektywna autoewaluacja w szkole - jak ja sensownie zaprojektować i przeprowadzić?, [w:] Ewaluacja w nadzorze pedagogicznym. Autonomia, red. G. Mazurkiewicz, Kraków 2010.

Mizerek H., Evaluation in Education in Poland: Initial Experience, [w:] 15-lecie Katedry UNESCO UWM w Olsztynie, red. J. Górniewicz, Olsztyn 2006.

Mizerek H., Ewaluacja edukacyjna. Interdyskursywne dialogi i konfrontacje, Kraków 2017.

Nalaskowski A., Nauczyciele z prowincji u progu reformy edukacji, Toruń 1998. 
Nowotniak J., Ewaluacja edukacyjna. Społeczne światy ewaluatorów, Kraków 2019.

Nowotniak J., Ukryty program szkolnej rzeczywistości, Szczecin 2002.

Okoń W., Wprowadzenie do dydaktyki ogólnej, Warszawa 1995.

Portelli J.P., Exposing the Hidden Curriculum, "Journal of Curriculum Studies" 1993, Vol. 25(4), DOI: https://doi.org/10.1080/0022027930250404.

Potulicka E., Paradygmat zmiany edukacyjnej Michaela Fullana, [w:] Szkice z teorii i praktyki zmiany oświatowej, red. E. Potulicka, Poznań 2001.

Rozporządzenie Ministra Edukacji Narodowej i Sportu z dnia 23 kwietnia 2004 roku w sprawie szczegółowych zasad sprawowania nadzoru pedagogicznego, wykazu stanowisk wymagających kwalifikacji pedagogicznych, kwalifikacji niezbędnych do sprawowania nadzoru pedagogicznego, a także kwalifikacji osób, którym można zlecać prowadzenie badań i opracowywanie ekspertyz (Dz.U. nr 89, poz. 845).

Rozporządzenie Ministra Edukacji Narodowej z dnia 7 października 2009 roku w sprawie nadzoru pedagogicznego (Dz.U. 2009, nr 168, poz. 1324).

Rylke H., Drugi program w szkole. Raport z badań pilotażowych, „Kwartalnik Pedagogiczny" 1984, nr 1.

Siarkiewicz E., Ostatni bastion, czyli jawne i ukryte wymiary pracy przedszkola, Kraków 2000.

Simons H., Getting to Know Schools in a Democracy. A Politics and Process of Evaluation, London 1987.

Stownik języka polskiego PWN, red. M. Szymczak, t. 3, Warszawa 1995.

Stownik terminów literackich, red. J. Sławiński, Warszwa 1988.

Sosniak L.A., The Generalist Educator: Making a Mark on Curriculum Studies, [w:] A Life in Classrooms. Philip W. Jackson and the Practice of Education, eds. D.T. Hansen, M.E. Driscoll, R.V. Arcilla, New York-London 2007.

Speer S., Peer Evaluation and Its Blurred Boundaries: Results from a Meta-evaluation in Initial Vocational Education and Training, "Evaluation" 2010, Vol. 16(4), DOI: https://doi.org/10.1177/1356389010382265.

Stake R., Studium przypadku, [w:] Ewaluacja wedukacji, red. L. Korporowicz, Warszawa 1997.

Stake R., The Art of Case Study Research, London 1995.

Stake R., Abma T.A., Responsive evaluation, [w:] Encyclopedia of Evaluation, New Delhi 2005.

Śliwerski B., Milerski B., Leksykon PWN. Pedagogika, Warszawa 2000.

Trzebiński J., Twórczość a struktura pojęć, Warszawa 1981.

Żłobicki W., Ukryty program w edukacji. Między manipulacją a niewiedza, Kraków 2003.

Summary: The article discusses the ways the hidden curriculum category can be applied in pedagogical studies and research. Hidden curriculum in the use of evaluation of the system of education is the major of analysis. The author referred particularly to the internal evaluation, which was re-introduced in 2009, along with the changes of the educational state supervisory.

Keywords: hidden curriculum; evaluation in education; internal evaluation; self-evaluation 